J. Clin. Chem. Clin. Biochem.

Vol. 24, 1986. pp. 243-250

(?) 1986 Walter de Gruyter \& Co.

Berlin. New York

\title{
An Optimized Micromethod for Determining the Catalytic Activity of Serum Ribonuclease
}

\author{
By $K$. Jung
}

Abteilung für experimentelle Organtransplantation, Bereich Medizin (Charité) der Humboldt-Universität zu Berlin, Berlin, DDR

(Received September 9/December 12. 1985)

Summary: An optimized assay is described for the catalytic activity determination of serum ribonuclease, using polycytidylic acid as substrate and measuring the released acid-soluble ultra-violet absorbing products. Recommended final reaction concentrations are $0.3 \mathrm{mmol} / 1$ polycytidylic acid, $200 \mathrm{mmol} / 1 \mathrm{imidazole} / \mathrm{HCl}$ buffer, $\mathrm{pH} 7.0$, and $50 \mathrm{mmol} / \mathrm{l} \mathrm{NaCl}$. Optimal concentrations for the precipitation procedure, guaranteeing sufficient precipitation and minimal decomposition of unreacted substrate, are $160 \mathrm{mmol} / \mathrm{l}$ perchloric acid and $4 \mathrm{mmol} / 1$ lanthanum nitrate. Coefficients of variation for the method (within series and between days) ranged from 2.2 to $7.9 \%$. No sex-related differences of catalytic activity were observed. In 63 blood donors with normal values of serum creatinine, the upper limit of the reference intervals (99th percentile) was 33.7 $\mathrm{kU} / \mathrm{l}$.

\section{Eine optimierte Mikromethode zur Bestimmung der katalytischen Aktivität der Ribonuclease im Serum}

Zusammenfassung: Eine optimierte Methode zur Bestimmung der katalytischen Aktivität der Ribonuclease im Serum unter Verwendung des Substrats Polycytidylsäure wird beschrieben. Als optimale Reaktionsbedingungen wurden $0.3 \mathrm{mmol} / 1$ Polycytidylsäure, $200 \mathrm{mmol} / 1$ Imidazol/HCl-Puffer $(\mathrm{pH} \mathrm{7,0)}$ und $50 \mathrm{mmol} / \mathrm{l} \mathrm{NaCl}$ ermittelt. $160 \mathrm{mmol} / \mathrm{l}$ Perchlorsäure und $4 \mathrm{mmol} / \mathrm{l}$ Lanthannitrat sind die Konzentrationen des StoppReagenses; diese Konzentrationen verhindern eine unspezifische Freisetzung von UV-absorbierenden Produkten während der Präzipitation des nicht umgesetzten Substrats. Die Variationskoeffizienten für die Methode (serielle und zeitliche Präzision) lagen zwischen 2,2 und 7,9\%. Das obere Referenzintervall (99 Perzentile) betrug bei 63 Blutspendern $33,7 \mathrm{kU} / 1$.

\section{Introduction}

Ribonuclease (ribonucleate $3^{\prime}$-pyrimidino-oligonucleotidohydrolase; EC 3.1.4.22) has been assumed to be a valuable indicator for various pathological conditions $(1-12)$. Based on its endonucleolytic action, its determination is usually performed spectrophotometrically by measuring the absorbance of the short chain oligonucleotides produced enzymatically. However, among the numerous methods used, none takes into account the general optimization principles for catalytic activity measurements (13). Although pancreatic and serum ribonuclease, due to their isoen- zyme patterns, differ in substrate specificity $(14,15)$, methods mostly developed for the former have been transferred to the serum enzyme assay $(4,7,16,17)$. As a result of this insufficient standardization, the widely used substrate, polycytidylic acid, has been recommended in substrate concentrations ranging from 0.54 to $1.92 \mathrm{mmol} / \mathrm{l}(4,17)$. Therefore, in the current study the influence of different analytical variables on the catalytic activity of serum ribonuclease has been examined, and an optimized method using polycytidylic acid as substrate is described. 


\section{Results}

\section{Analytical variables}

\section{Buffer and $p H$}

The catalytic activity of ribonuclease was measured in the buffer solutions of tris(hydroxymethyl)aminomethane, N-tris(hydroxymethyl)methyl-2-aminoethanesulphonic acid, imidazole, and potassium phosphate in the range $\mathrm{pH} 5.5$ to $\mathrm{pH} 8.0$ (fig. 1). The $\mathrm{pH}$ optimum is clearly affected by the buffers used. The highest catalytic activity was obtained in $200 \mathrm{mmol} / 1$ imidazole/ $\mathrm{HCl}$ buffer, $\mathrm{pH} 7.0$ (fig. 1 and 2). In the other buffers investigated, the catalytic activity decreased with increasing concentrations (not shown).

Several batches of imidazole from different producers (Ferak, Berlin; E. Merck, Darmstadt; Fluka, Buchs) were examined. Using these different imidazoles, similar catalytic activities but greatly differing blank values were observed. The lowest reagent blank value (about $0.100 \mathrm{~A}$ ) was obtained with imidazole supplied by Fluka.

\section{Polycytidylic acid}

The effect of the polycytidylic acid concentration on catalytic ribonuclease activity was examined between 0.03 and $1.8 \mathrm{mmol} / \mathrm{l}$ in serum and urine samples from healthy persons and serum samples from patients with elevated serum creatinine (fig. 3). The catalytic

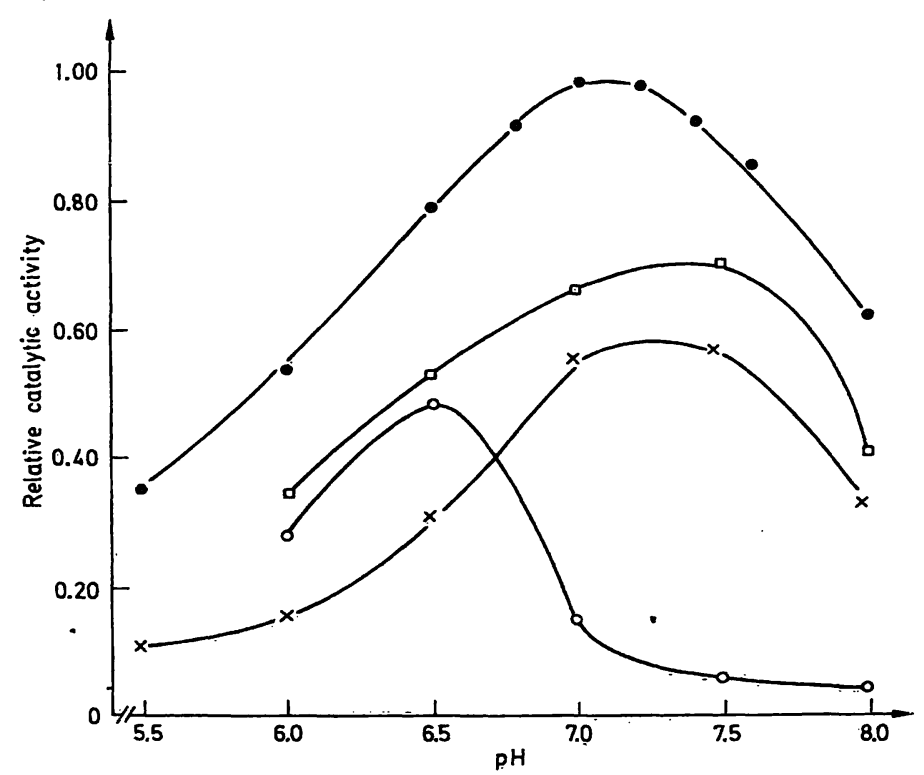

Fig. 1. Dependence of the catalytic activity of serum ribonuclease on $\mathrm{pH}$. The final buffer concentrations were $50 \mathrm{mmol} / 1$ of tris(hydroxymethyl/aminomethane $/ \mathrm{HCl}$ (口- $\square$ ), $50 \mathrm{mmol} / \mathrm{l}$ of $\mathrm{N}$-tris(hydroxymethyl)methyl-2-aminoethanesulphonic acid/NaOH $(x-x), 50 \mathrm{mmol} / 1$ of potassium phosphate $(\mathrm{O}-\mathrm{O})$, and $200 \mathrm{mmol} / \mathrm{l}$ of imidazole $/ \mathrm{HCl}$ (-) containing $0.3 \mathrm{mmol} / 1$ of polycytidylic acid and $50 \mathrm{mmol} / 1 \mathrm{NaCl}$. Each point is the mean of triplicates. activity increased in all the three samples investigated up to about $0.3 \mathrm{mmol} / 1$ of polycytidylic acid, whereas a typical substrate inhibition effect was observed at higher concentration of polycytidylic acid. However, the extent of inhibition differed among the samples. This phenomenon of different substrate inhibition may reflect the different isoenzyme composition of the samples investigated. The polycytidylic acid concentration of $0.3 \mathrm{mmol} / 1$ was selected for our proposed method.

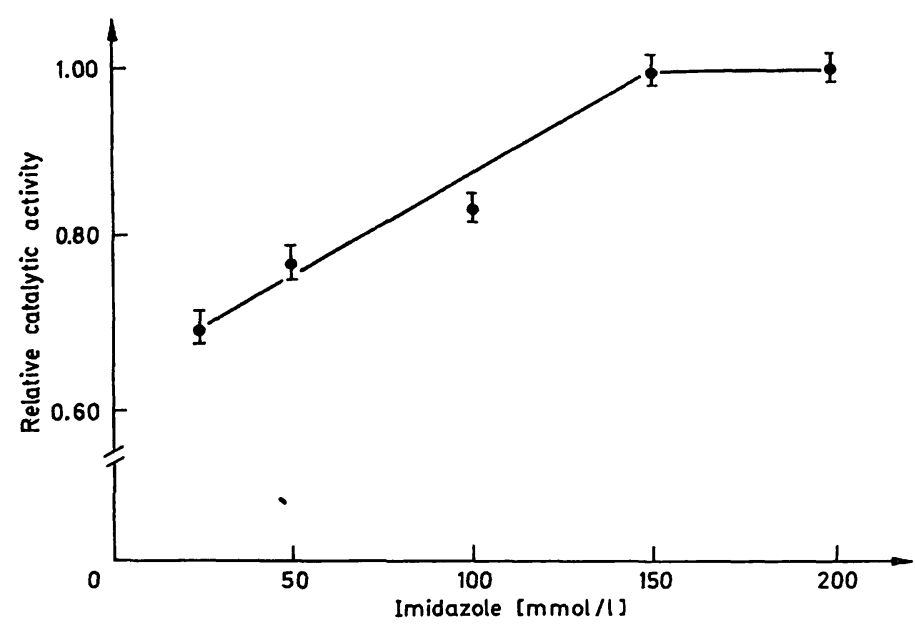

Fig. 2. Dependence of the catalytic activity of serum ribonuclease on imidazole concentration. Imidazole concentration ( $\mathrm{pH} 7.0)$ was varied as indicated. Concentration of polycytidylic acid and of $\mathrm{NaCl}$ as in fig. 1. Each point is the mean of triplicates.

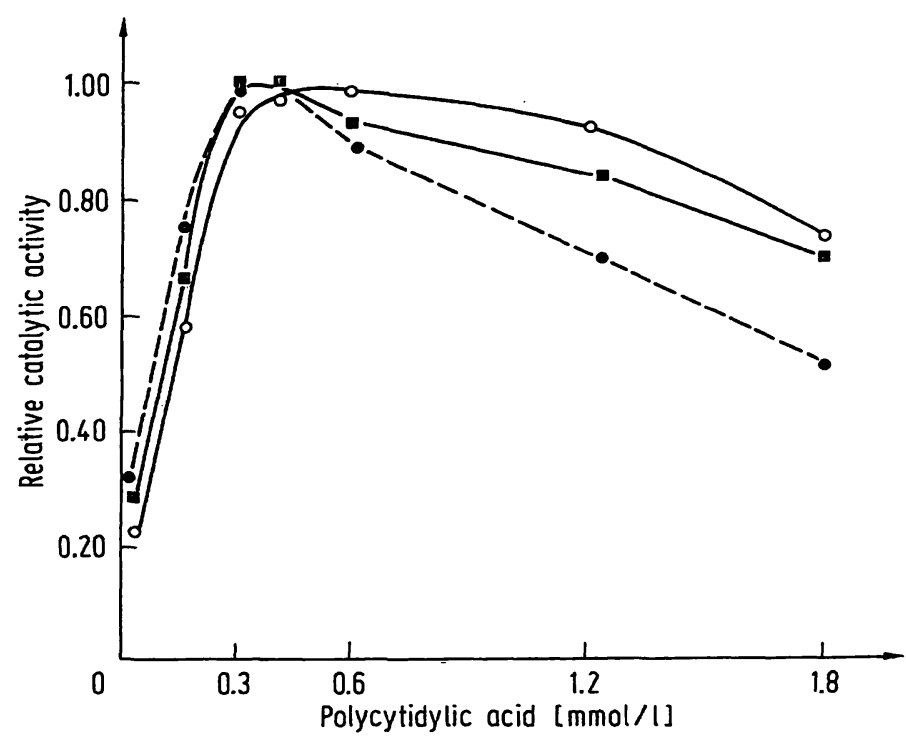

Fig. 3. Dependence of catalytic activity of serum ribonuclease on the polycytidylic acid concentration. Final reaction conditions: $200 \mathrm{mmol} / \mathrm{l}$ imidazole/ $\mathrm{HCl}$ buffer $(\mathrm{pH} 7.0)$, $50 \mathrm{mmol} / 1 \mathrm{NaCl}$, and polycytidylic acid as indicated. Three different samples were used:

$0-\ldots$, pool of serum samples with normal values of serum creatinine (mixture of serum samples as indicated in "Materials and Methods");

, pool of serum samples with increased values of serum creatinine (mixture of 10 samples obtained from kidney transplant recipients);

0 , urine samples, obtained from healthy persons. 


\section{Influence of cations}

Numerous cations have been tested in the reaction mixtures for ribonuclease determination $(20-22)$, but there is some disagreement over their effects on the catalytic activity of ribonuclease (23). Comparing the data in the literature, it is obvious that the effect of cations on ribonuclease activity depends on the buffer and substrate used (23). Therefore, their effects under the above-stated reaction conditions had to be investigated. The monovalent cations, sodium and potassium, were studied at concentrations from 0 to $300 \mathrm{mmol} / \mathrm{l}$, the divalent cations, magnesium and calcium (all with chloride as anions), from 0 to $8 \mathrm{mmol} / \mathrm{l}$. The effect of $\mathrm{NaCl}$ is shown. in table 2 . A similar effect was demonstrated for $\mathrm{KCl}$. With increasing concentrations the inhibitory influence of both cations is evident. $\mathrm{MgCl}_{2}$ and $\mathrm{CaCl}_{2}$ showed about the same activation effect $(20-30 \%)$ in the concentrations studied. A combination of optimal sodium and divalent cation concentrations, caused a decrease in catalytic enzyme activity (tab. 2). Because of these results, together with the results outlined in the chapter of stability, $50 \mathrm{mmol} / \mathrm{l}$ of $\mathrm{NaCl}$ were included in the reaction mixture.

Tab. 2. Effect of $\mathrm{NaCl}$ and other cations on the analytic activity of serum ribonuclease. Data are given as fraction (arithmetic mean $\pm S D ; n=3$ ) of catalytic activity obtained without cation added $(22.4 \mathrm{kU} / \mathrm{l}) . \mathrm{Ca}^{2+}$ and $\mathrm{Mg}^{2+}$ when present, were at a concentration of $4 \mathrm{mmol} / \mathrm{l}$. Concentrations are final concentrations.

\begin{tabular}{ll}
\hline $\begin{array}{l}\mathrm{NaCl} \\
(\mathrm{mmol} / \mathrm{l})\end{array}$ & Catalytic activity fraction \\
\hline 0 & $1.000 \pm 0.038$ \\
50 & $1.230 \pm 0.027$ \\
$\left(+\mathrm{Ca}^{2+}\right)$ & $0.565 \pm 0.021$ \\
$\left(+\mathrm{Mg}^{2+}\right)$ & $0.395 \pm 0.029$ \\
$\left(+\mathrm{Ca}^{2+}+\mathrm{Mg}^{2+}\right)$ & $0.649 \pm 0.034$ \\
100 & $0.589 \pm 0.058$ \\
200 & $0.064 \pm 0.002$ \\
300 & $0.009 \pm 0.002$ \\
\hline
\end{tabular}

\section{Stop solution and precipitation procedure}

The influence of perchloric acid as well as lanthanum nitrate concentrations was examined (tab. 3). As final concentrations of the precipitating reagent 160 $\mathrm{mmol} / \mathrm{l}$ perchloric acid and $4 \mathrm{mmol} / \mathrm{l}$ lanthanum nitrate were selected as this combination leads to the lowest absorbance in the supernatant (tab. 3). Since the blank value is not essentially influenced by the perchloric acid concentration, it is assumed that a stronger perchloric acid concentration does not destroy polycytidylic acid but decomposes depolymerized products resulting from the ribonuclease attack upon polycytidylic acid. Therefore, the lowest absorbance in the supernatant (i. e. activity) indicates (tab. 3 ) that these conditions cause sufficient precipitation and minimized decomposition of these products.

\section{Linearity}

The method shows a linear response for the catalytic concentration of ribonuclease up to a net absorbance of about 0.900 under the given assay conditions (fig. 4). Taking into account this absorbance limit, linearity can be assumed over a reaction time of at least 30 min under the given conditions (fig. 5).

\section{Stability}

Owing to its high catalytic activity in serum, ribonuclease has to be diluted for measurement. At first the enzyme stability was tested after dilution. For this purpose, dilutions of 10 serum samples both with $150 \mathrm{mmol} / 1 \mathrm{NaCl}$ solution and with distilled water were prepared and then stored at room temperature (about $23^{\circ} \mathrm{C}$ ). Their activities were measured over a period of 3 hours. In comparison with their starting activities, the mean recoveries for the samples diluted with the saline solution after that time were $101 \%$ (standard deviation $4.5 \%$ ) and $117 \%$ (standard de-

Tab. 3. Influence of precipitating reagents on the catalytic activity of measured ribonuclease. Catalytic activities are arithmetic means $\pm S D$ of 4 determinations. Concentrations of reagents are final concentrations.

\begin{tabular}{|c|c|c|c|c|c|}
\hline \multirow[t]{3}{*}{ Activity } & \multicolumn{5}{|c|}{ Precipitating reagent } \\
\hline & \multicolumn{5}{|c|}{ A. Perchloric acid (mmol/l) } \\
\hline & 80 & 160 & 320 & 640 & 960 \\
\hline \multirow[t]{3}{*}{$\mathrm{kU} / \mathrm{l}$} & $22.5 \pm 6.4$ & $24.3 \pm 1.1$ & $31.8 \pm 1.1$ & $36.7 \pm 0.9$ & $45.4 \pm 0.6$ \\
\hline & \multicolumn{5}{|c|}{ B. $160 \mathrm{mmol} / \mathrm{l}$ perchloric acid plus lanthanum nitrate (mmol/l) } \\
\hline & 0 & 1.6 & $4:$ & 8 & 16 \\
\hline $\mathrm{kU} / 1$ & $23.2 \pm 0.7$ & $20.9 \pm 1.2$ & $18.8 \pm 1.4$ & $25.9 \pm 1.1$ & $\therefore 31.5 \pm 1.1$ \\
\hline
\end{tabular}




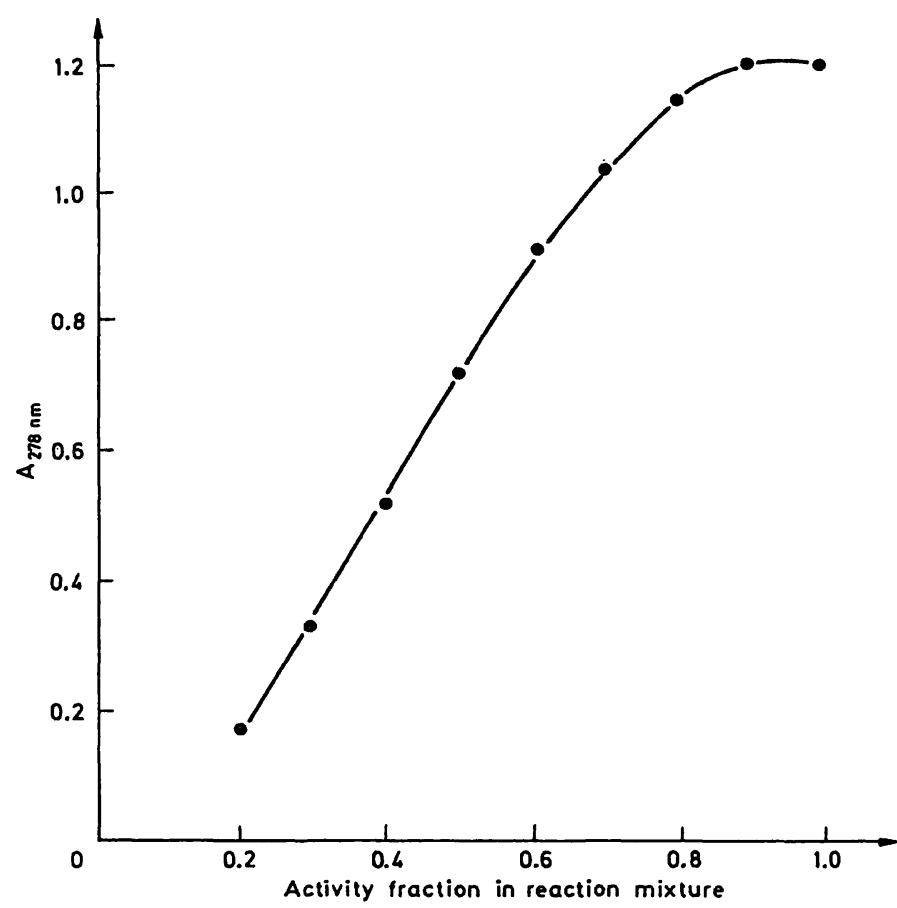

Fig. 4. Linearity of the assay. A serum sample was serially diluted with $150 \mathrm{mmol} / \mathrm{l}$ of $\mathrm{NaCl}$ solution to prepare different dilutions. Each point is the mean of triplicates.

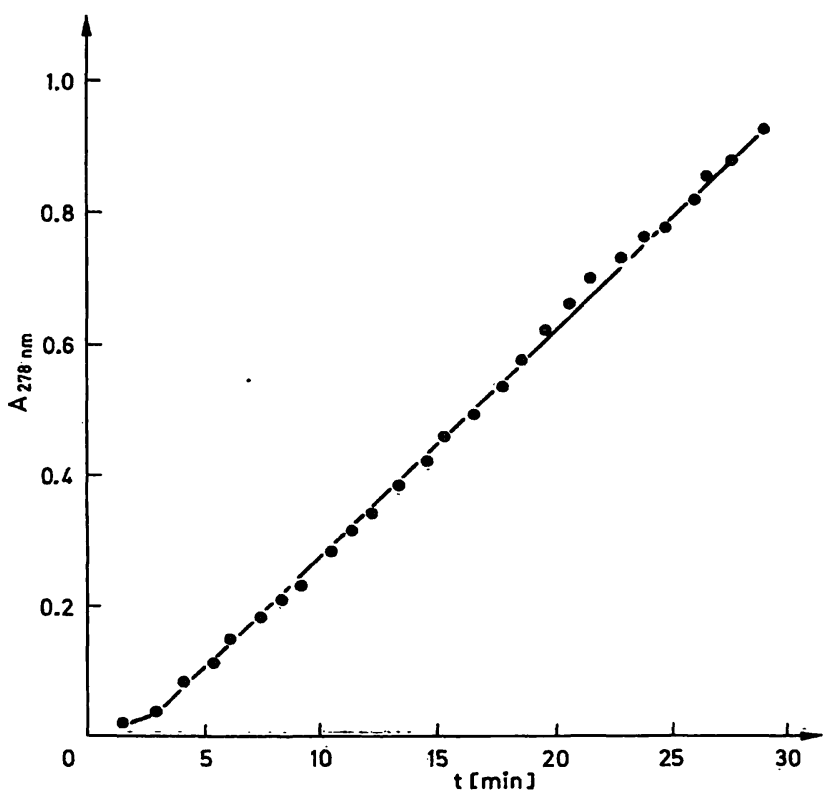

Fig. 5. Time-dependent linearity of the assay. The activity of a serum sample was investigated each minute over a reaction period of $30 \mathrm{~min}$.

viation $9.3 \%$ ) for those diluted with water. Because of this significant difference $(p<0.001)$ dilution of serum with a $150 \mathrm{mmol} / \mathrm{l} \mathrm{NaCl}$ solution is recommended. Thus the $\mathrm{NaCl}$ concentration in the reaction mixture is $50 \mathrm{mmol} / \mathrm{l}$, which is also best for the monovalent cation effect.

The stability of ribonuclease was studied on 10 serum samples stored at room temperature (about $23^{\circ} \mathrm{C}$ ), $4{ }^{\circ} \mathrm{C}$, and $-20^{\circ} \mathrm{C}$ (tab: 4 ).
At these temperatures, the samples did not lose their catalytic activities over 5 days. However, it is recommended that samples be stored at $-20^{\circ} \mathrm{C}$ when not tested within 3 days.

In the complete reaction mixture, the enzyme was stable for at least $30 \mathrm{~min}$ (see section on Linearity and fig. 5).

\section{Precision}

Table 5 shows our precision data for the method.

Comparison with method according to Reddi (7)

In comparison with the popular and often cited determination method of Reddi (7), our procedure resulted in a three-to-four-fold increase of sensitivity (fig. 6). Both methods showed results which correlate very well $(r=0.935)$.

Tab. 4. Stability of ribonuclease in serum under different storage conditions. Catalytic activity measured in each of 10 different serum samples within 3 hours of drawing the blood was considered to be 1.00. Data are given as fraction of this starting catalytic activity (arithmetic mean $\pm \mathrm{SD}$ ).

\begin{tabular}{llll}
\hline $\begin{array}{l}\text { Storage } \\
\text { time } \\
\text { (d) }\end{array}$ & \multicolumn{3}{l}{ Fraction of starting catalytic activity } \\
\cline { 2 - 4 } & $23^{\circ} \mathrm{C}$ & $4^{\circ} \mathrm{C}$ & $-20^{\circ} \mathrm{C}$ \\
\hline 1 & $1.01 \pm 0.07$ & $1.05 \pm 0.04$ & $1.03 \pm 0.07$ \\
2 & $0.99 \pm 0.08$ & $1.00 \pm 0.07$ & $1.02 \pm 0.04$ \\
3 & $0.95 \pm 0.10$ & $1.05 \pm 0.05$ & $1.02 \pm 0.06$ \\
5 & $0.96 \pm 0.11$ & $1.04 \pm 0.09$ & $1.08 \pm 0.08$ \\
7 & $0.73 \pm 0.16$ & - & $1.01 \pm 0.10$ \\
14 & $0.52 \pm 0.21$ & - & $0.99 \pm 0.08$ \\
\hline
\end{tabular}

Tab. 5. Precision data for the determination of catalytic activity of ribonuclease.

\begin{tabular}{llll}
\hline $\mathrm{n}$ & \multicolumn{3}{l}{ Catalytic activity (kU/l) } \\
\cline { 2 - 4 } & $\mathrm{x}$ & SD & CV (\%) \\
\hline \multicolumn{4}{l}{ Within series } \\
10 & 9.7 & 0.31 & 3.19 \\
10 & 28.1 & $0.62^{\mathrm{a}}$ & 2.20 \\
10 & 28.0 & $1.20^{\mathrm{a}}$ & 4.28 \\
& \multicolumn{3}{c}{ Between series } \\
14 & 26.5 & 2.09 & 7.88 \\
\hline
\end{tabular}

a Determinated by two different investigators.

b During a period of $\mathbf{4 2}$ days. 


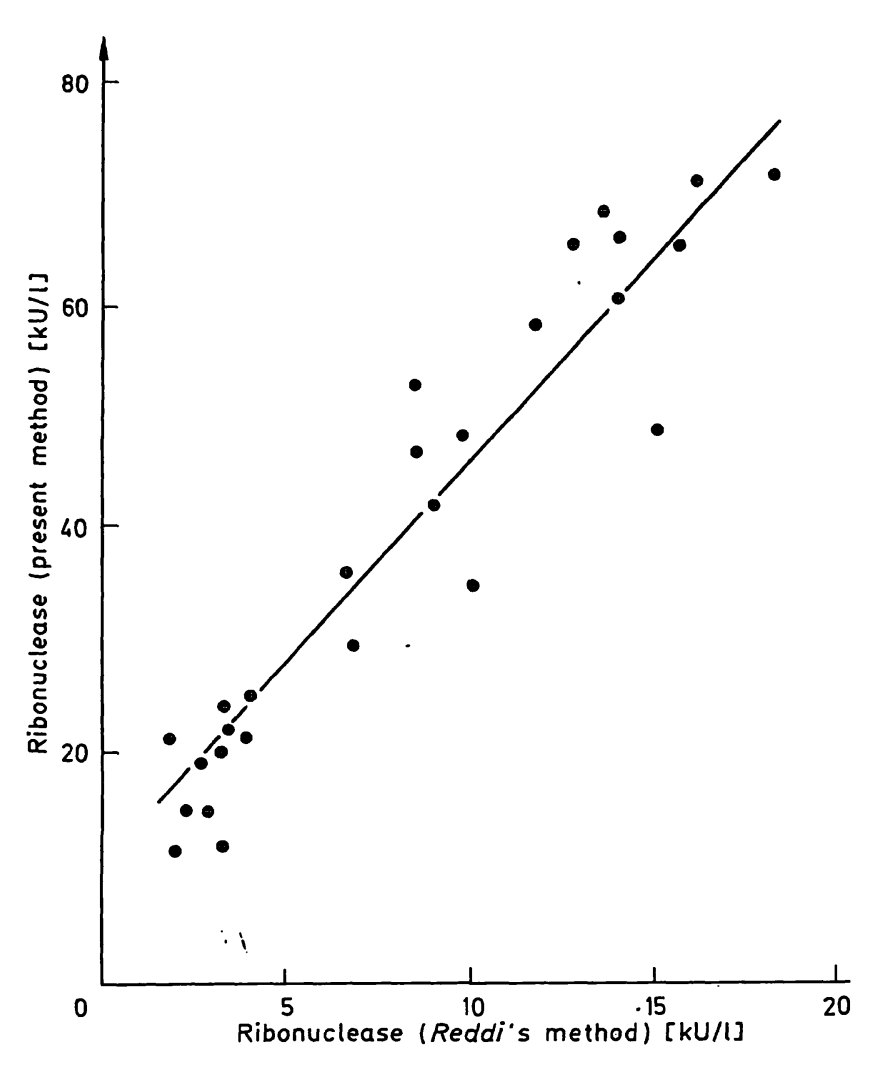

Fig. 6. Comparison of the catalytic activity of serum ribonuclease as determined by the present method (ordinate) and by use of the method according to Reddi (7) (abscissa). $\mathrm{y}=3.39 \mathrm{x}+11.5 ; \mathrm{r}=0.935 ; \mathrm{n}=27$.

\section{Reference intervals in healthy adults}

To determine preliminary reference ranges, the catalytic activity of ribonuclease was assayed in the sera of blood donors ( $n=63 ; 32$ females, 31 males) with normal values of serum creatinine. The age structure of women (ages 23 to 53 years; mean value: $37.1 \pm$ 8.6 years) did not differ from that of men (ages 22 to 55 years; mean value: $34.1 \pm 8.5$ years). Distributions of ribonuclease values, estimated by use of the $\chi^{2}$-test, did not show any significant deviations from Gaussian distribution. No sex-related differences were found $(22.2 \pm 5.1 \mathrm{kU} / \mathrm{l}$ for women; $21.5 \pm 5.2$ $\mathrm{kU} / 1$ for men). Therefore, the preliminary reference intervals listed in table 6 were established with the combined data of males and females.

\section{Discussion}

Although the diagnostic evidence of ribonuclease in various diseases has been discussed $(1-12)$, detailed information is lacking because methodical problems in the determination of this enzyme have not yet been resolved. Recently, many authors have attempted to investigate this problem more systematically with regard to the different methods used in activity measurements $(10,21,23)$.

Various methods have been employed for ribonuclease determination: spectrophotometric methods differing with their use of substrates, for example RNA from yeast $(1-3)$, transfer RNA from yeast and Escherichia coli (23), and different polynucleotides $(15,17,24)$, methods using radiolabeled substrates (25), and radioimmunoassays (14). In routine diagnostics, spectrophotometric methods are of special interest. In comparison with naturally occurring substrates like RNA from yeast, the use of synthetic substrates offers advantages for the standardization of methods. Polycytidylic acid (7) has been recommended for this purpose although the different isoenzymes of serum ribonuclease are not equally able to hydrolyse this substrate $(14,15)$. In comparative determinations of catalytic ribonuclease activity in sera, Scott (23) found a good correlation between the values of the catalytic activity of the so-called total ribonuclease (determined with tRNA) and the cytidine-specific ribonuclease. However, it is surprising that in general the method elaborated for pancreatic ribonuclease $(16,17)$ is also used to determine this enzyme in serum $(7,24)$. Corbishley et al. (10) became aware of this problem by the high imprecision data that they obtained with the original method according to Reddi (7). By decreasing the substrate concentration Corbishley et al. (10) succeeded in improving the analytical reliability of ribonuclease measurement. Unfortunately, they did not systematically study other analytical variables like buffer and $\mathrm{pH}$, cation effects, and the precipitation procedure. In order to as far as possible eliminate the mentioned effect of isoenzymes on the development of the method the experiments were performed with a pool of 30 serum samples obtained from healthy persons.

Tab. 6. Parametric (Gaussian) percentile calculations of catalytic concentrations of ribonuclease in 63 blood donors with normal creatinine values. The 50th percentile is given with standard deviation. Further details are given in the text.

\begin{tabular}{|c|c|c|c|c|c|c|c|}
\hline & \multicolumn{7}{|c|}{ Percentiles } \\
\hline & 1 & 10 & 50 & . & 90 & 97.5 & 99 \\
\hline Ribonuclease $(k U / 1)$ & 9.9 & 15.3 & 21. & & 28.3 & 30.2 & 33.7 \\
\hline
\end{tabular}


The substrate concentration we recommend is comparable to the concentration proposed by Corbishley et al. (26) but giving no further details. The data show that this concentration is also acceptable for serum enzyme determinations in patients with renal dysfunction and for ribonuclease measurements in urine.

For the determination of ribonuclease with polycytidylic acid as substrate, buffers like potassium phosphate (21), potassium phosphate combined with sodium borate (7), and tris(hydroxymethyl) aminomethane (4) were used. As our experiments clearly illustrate, the $\mathrm{pH}$ optimum of the catalytic activity of ribonuclease depends on the buffer used. Whereas the phosphate buffer in increased concentrations inhibits ribonuclease, imidazole acts like an activator. Similar buffer effects have been observed with transfer RNA as substrate (23). Thus the observed $\mathrm{pH}$ behaviour of ribonuclease is also a result of a specific buffer ion effect. The expression "acid" and "alkaline" ribonuclease corresponding to the $\mathrm{pH}$ optimum in various buffers is not advisable and should be avoided (26). Employing the isoelectric focusing method, three isoenzymes of ribonuclease in their basic, neutral, and acid forms were detected in human serum (12).

Different procedures have been described for stopping the catalytic activity of ribonuclease after the incubation period chosen and for precipitating the undegraded substrate $(17,27)$. The reaction products in the supernatant and consequently the measured absorbance also depend on the precipitating reagent used (e. g. perchloric acid alone or in combination with lanthanum nitrate or uranium salts) (17). The precipitation technique using perchloric acid and lanthanum nitrate has been mostly recommended but there has not yet been a systematic study of the effects of these compounds. In general, $0.6 \mathrm{~mol} / 1$ of perchloric acid is used as a final concentration to precipitate the unreacted substrate $(7,26)$. Our results prove that it is necessary to reduce this concentration to avoid any unspecific decomposition.

Compared with the traditional method for determining ribonuclease activity with polycytidylic acid according to Reddi (7), our modified method is more sensitive and has the following advantages:

\section{References}

1. Berman, L. B. \& Houck, J. C. (1958) Proc. Soc. Exp. Biol. Med. 97, 175-177.

2. Rabinovitch, M., Liberman, B. \& Fausto, N. (1959) J. Lab. Clin. Med. 53, 563-568.

3. Levy, A. L. \& Rottino, A. (1960) Clin. Chem. 6, 43-51.

4. Fink, K., Adams, W. S. \& Skoog, W. (1971) Amer. J. Med. $50,450-457$.
1. The method is optimized with regard to all the analytical variables which influence the reaction rate of ribonuclease and with regard to the measurement of products caused by this ribonuclease action.

2. Being a micromethod, it costs less. Reagents for one test cost about 15 cents in comparison with about one dollar for the method of Reddi (7).

3. By using complete buffer/substrate mixture and avoiding further dilutions after stopping the reaction, one person is able to make about 200 determinations a day.

We were not able to perform comparative determinations between our method and the recommended method with tRNA as substrate (26). But Scott (23) observed about five fold higher catalytic ribonuclease activities determined with polycytidylic acid as substrate than with tRNA. As our modified method resulted in a three to four fold increased sensitivity in comparison with the traditional method for determining ribonuclease activity with polycytidylic acid according to Reddi (7), we assume that ten to twenty fold higher values are obtained with our method compared with the method using tRNA as substrate.

To characterize the method further, the catalytic concentration of ribonuclease activity was measured in blood donors. It is generally accepted that ribonuclease increases with age and is independent of sex (24). The age influence was not investigated because our subjects had relatively close ages. Therefore, our reference intervals can only be considered preliminary for adults. Our values, however, are higher than those so far described with the substrate polycytidylic acid (24). Previously reported mean values for subjects in the age range 20 to 50 years lie between 10 and 13 $\mathrm{kU} / \mathrm{l}$. With our optimized reaction conditions, we found a mean value for $21.8 \mathrm{kU} / 1$.

\section{Acknowledgement}

I gratefully thank Mrs. Carmen Reinholdt for skilful assistance in the determination of reference values and Mrs. Bärbel Dahms for typing the manuscript.
5. Humphrey, R. L., Karpetsky, R. P., Neuwelt, E. A. \& Levy, C. C. (1977) Canc. Res. 37, 2015-1022.

6. Rabin, E. Z., Weinberger, V. \& Tattrie, B. (1977) Clin. Chim. Acta 78, 235-242.

7. Reddi, K. K. (1978) Clin. Biochem. 11, 133-134.

8. Thomas, J. M., Eigen, H. \& Hodes, M. E. (1981) Clin. Chim. Acta 111, 199-209. 
9. Rabin, E. Z., Algom, D., Freedman, M. H., Geunther, L., Dardick, I. \& Tattrie, B. (1981) Nephron 27, 254-259.

10. Corbishley, T. P., Greenway, B., Johnson, P. J. \& Williams, R. (1982) Clin. Chim. Acta 124, 225-233.

11. Akagi, K., Tsji, H., Kajiwara, E., Murai, K. \& Shikata, T. (1983) Clin. Chim. Acta 135, 83-87.

12. Hishi, S., Sakaguchi, S. \& Kanno, T. (1984) Clin. Chim. Acta 136, 155-164.

13. Bowers Jr., G. N., Bergmeyer, H. U., Hørder, M. \& Moss, D. W. (1979) J. Clin. Chem. Clin. Biochem. 18, 89-95.

14. Kurakowa, E., Ogawa, M., Kurihara, M., Ohta, T., Kitahara, T., Kosaki, G., Iwama, M., Ohgi, K. \& Irie, M. (1983) Clin. Chim. Acta 128, 83-93.

15. Akagi, K., Murai, K., Hirao, N. \& Yamanaka, M. (1976) Biochim. Biophys. Acta 442, 368-378.

16. Zimmerman, S. B. \& Sandeen, G. (1965) Anal. Biochem. $10,444-449$.

17. Reddi, K. K. (1975) Biochem. Biophys. Res. Commun. 67, 110-118.

18. Heppel, L. A., Ortitz, P. J. \& Ochoa, S. (1957) J. Biol. Chem. 229, 679-694.
19. Handbook of Biochemistry, Selected Data for Molecular Biology (Sober, H. A., ed.) CRC Press, Cleveland 1973, p. G-66.

20. Levy, C. C., Mitch, W. E. \& Schmukler, M. (1973) J. Biol. Chem. 248, 5712-5719.

21. Rabin, E. Z. \& Weinberger, V. (1975) Biochem. Med. 14, $1-11$.

22. Bardon, A., Sierakowska, H. \& Shugar, D. (1976) Clin. Chim. Acta 67, 231-243.

23. Scott, P. H. (1979) Anal. Biochem. 100, 233-239.

24. Francesconi, M., Meryń, S., Moser, K. \& Bauer, K. (1981) J. Clin. Chem. Clin. Biochem. 19, 17-20.

25. Lee, C. C., Trotman, C. N. A. \& Tate, W. P. (1983) Anal. Biochem. 135, 64-68.

26. Corbishley, T. P., Johnson, P. J. \& Williams, R. (1984) Serum ribonuclease. In: Methods of Enzymatic Analysis, Vol. 4 (Bergmeyer, H. U., ed.). Verlag Chemie, Weinheim, pp. $134=143$.

27. Razzell, W. E. (1963) J. Biol. Chem. 238, 3055-3057.

Docent Dr. sc. K. Jung

Abteilung für experimentelle

Organtransplantation

Bereich Medizin (Charité)

der Humboldt-Universität zu Berlin

Leninallee 49

DDR-1017 Berlin 